\title{
Histological And Histochemical Studies After Partial Hepatoectomy In Liver And Spleen Of Rats
}

\author{
Abdel Motaal. N.A.R. \\ Radiation Biology Department, National Center for Radiation Research \\ and Technology, Cairo, Egypt
}

\begin{abstract}
Introduction :- The aim of this investigation is to study the effect of partial hepatoectomy on the histology and histochemistry of liver and spleen of male rats.

Material And Methods:- Twenty four rats were used in the present study and were divided into four groups"six rats each".group(I) and classified into four groups: Negative control group (I). 6 rats and group (II) hepatoectomized rats were given sub. Cut $0.1 \mathrm{ml}$ vitamin $\mathrm{K}$ 3 days consequently before surgical hepatectomy was performed. Histopathological examination of liver and spleen and frozen sections for alkaline phosphatase demonstration were undertaken in the $1^{\text {st }}$ day, $7^{\text {th }}$ day and $15^{\text {th }}$ day following the surgical operation.

Results:- The histopathological results were manifested in hepatoectomized rats as congested portal vein, vacuolation and pyknosis in liver cells, fibrosis inflammatory cells infiltration around hepatic vein and increasing kupffer cells. In splenic tissue the histopathological changes were in the form of ill defined pulps with marked congestion and necrotic nuclei. After $15^{\text {th }}$ days of operation marked recovery in both white and red pulps were recorded. The histochemical examination of alkaline phsophatase revealed marked attenuation after $1^{\text {th }}$ and $7^{\text {th }}$ days of operation in both liver and spleen of hepatoectomized rats followed by regeneration after $15^{\text {th }}$ day of operation in comparison to the control group.
\end{abstract}

Keywords: Hepatic., Spleen, Liver, ALP.

\section{Introduction}

It is well known that a substantial increase in fibrosis usually leads to potentially lethal cirrhosis of the liver in humans (Ulieno et al, 2003) Although the pathogenesis of liver fibrosis is not quite clear, there is no doubt that the reactive oxygen species (ROS) play an important role in the pathological changes particularly in cases of liver toxicity and radiation exposure (Maisin, 1998). On the other hand, many investigators have been studied the restoration of the liver rat following partial hepatectomy (Higgins et al, 1931; Hakcova et al 1996 and Kropacova et al., 1998.)

Nagino et al, (1999) correlated serum alkaline phoephatase (ALP) levels with liver function and its regeneration after major hepatoectomy. They concluded that serum ALP levels can be an indicator of liver function after hepatectomy, but it doesn't reflect morphological regeneration of the liver.
However, Osada and Saji, (2004) reported the clinical significance of monitoring alkaline phosphates level to estimate postoperative liver failure after hepatectom

\section{Material And Methods}

Drug:

$0.1 \mathrm{ml}$ viatmine $\mathrm{K}$ (anticoagulant) was injected subcutaneously for 3 days consecutive days before surgical operation. according to Ainley and James ,(1977)

Animals:

In this study, 24 male albino rats ( 100 - 120gm) were used. The animals were housed in cages under good ventilation , adequate standard diet and free supply of water.

The animals were divided into:

Group I: Negative control group consisted of 6 rats. 
Group II: III\&IV;Each group consisted of 6 rats. Animals were injected with $0.1 \mathrm{ml}$ vitamin " $\mathrm{K}$ " . 3 days before surgical operation, $2 / 3$ partial hepatoectomy(from the left lope)was performed according to Higgins et al, (1931) and Hakova et al, (1996), Animals were anesthesized with ether,dissected and small fresh piece of liver, transverse section of spleen were obtained after $1^{\text {st(gr } 1)}, 7^{\text {th(gri1) }}$, and $15^{\text {th(grlv) }}$ days following the operation. Tissues were fixed in neutral formal saline, dehydrated in ascending grades of alcohol, cleared in xylol,and embedded in paraffin wax. Samples were serially sectioned at a thickness of 5-6 $\mu$. The sections were then stained using haematoxyline and eosin. Frozen sections were cut at $5-6 \mu$ and stained with Gomori's stain to demonstrate the alkaline phosphates enzyme activity according to Pearse, (1975).

\section{Results:}

\section{Liver:}

Examination of liver sections from control groups revealed normal histological structure of hepatic tissue Fig (1-1). Histopathological changes of liver after $2 / 3$ partially hepatoedomy revealed congested hepatic portal vein, hypertrophied hepatocytes. in presence of kupffer cells after $1^{\text {st }}$ day of treatment were noticed. Fig. (1-2).

Mean while, $7^{\text {th }}$ day post-treatment proved distortion of the normal architecture of hepatocytes, widening of central vein, fatty degeneration besides some nuclei appeared pyknotic and others karyolysis were detected (Fig 1-3).

After $15^{\text {th }}$ day of the treatment, showed massive number of kupffer cells appeared in the spaces between the blood sinusoids with vacuolated cytoplasm were observed (Fig. 1-4).

Spleen:

Histological examination of spleen sections from control showed the normal histoloical structure of spleen from white and red pulp. The white pulp consists of lymphoid follicles while the red pulp consists of different blood elements (Fig 25 on the other hand microscopic examination of spleen $2 / 3$ partial hepatoectomy on $1^{\text {st }}$ day of treatment showed internal splenic hemorrhage, ill defined pulps since larg areas are destructed (Fig. 2-6).

Histological sections from $2 / 3$ partially hepatoectomy rats revealed distorted splenic architecture with necrotic nuclei and others karyolysis after $7^{\text {th }}$ days of treatment (Fig 2-7).

However, spleen sections of hepatoectomrized rats after $15^{\text {th }}$ days of treatment illustrated marked recovery both in white and red pulp were detected (Fig 2-8).

\section{Histochemical studies in rat liver:}

Alkaline phosphatase demonstration:

The present data in liver hepatocytes revealed moderate dark brown granules stain of alkaline phosphates activity in control rats (Fig 3-9).

Regarding the present histochemical data revealed marked decrease in phosphatase activity after $1^{\text {st }}$ and $7^{\text {th }}$ days of treatment Located in the parenchyma of liver tissues were detected (fig 3-10, 11) Later, after $15^{\text {th }}$ days of treatment, revealed moderate distrbution of alkaline phosphates activity were noticed (fig 3-12).

Histochemical studies in rat spleen:

Alkaline phosphates activity:

The histochemical findings revealed negative white pulp for alkaline phosphates stain in control rats, whereas positive in red pulp alkaline phosphates activity were detected. (fig $4-13$ ).

The present data showed a decrease in alkaline phosphates activity of rat in splenic red pulps after $1^{\text {st }}$ and $7^{\text {th }}$ days of treatment were detected (fig 4-14, 15) finally, modeate reaction in phosphates activity post $15^{\text {th }}$ days of treatment were observed (Fig 4-16). 


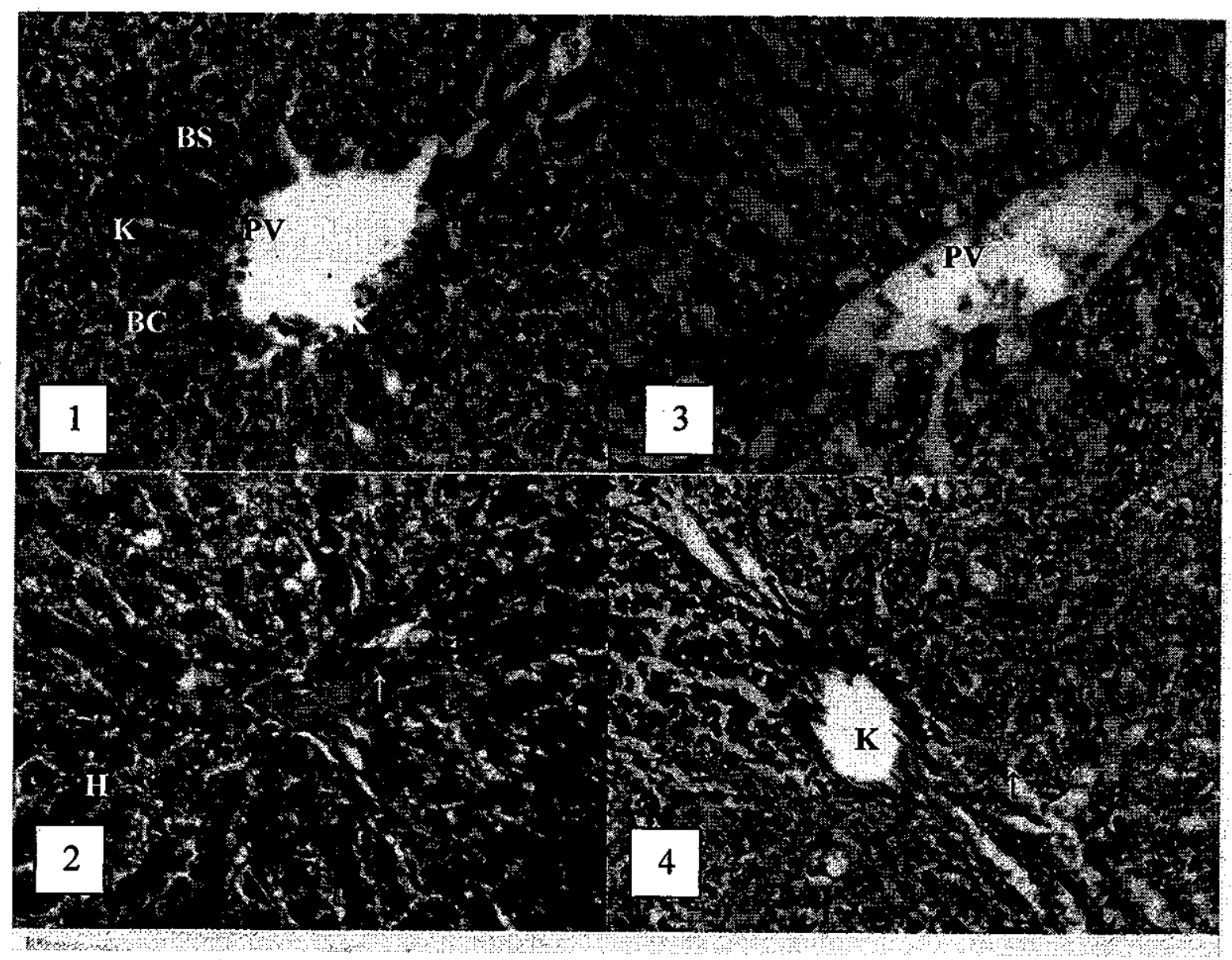

Fig. (1) Photomicrograph of sections in liver of control and experimental rat group (II).

1 - Photomicrograph of a section in liver of control rat showing normal histological structure, portal vein $(\mathrm{PV})$, hepatocytes $(\mathrm{H})$, kupffer cells(K), blood sinusoids (BS) and bile canalculi $(\mathrm{Bc})(\mathrm{Hx} \& \mathrm{E}$ $\mathrm{x} 250$ ).

2 - Photomicrograph of a section in liver of group II after $1^{\text {st }}$ day of treatment showing: congested hepatic portal vein $(\uparrow)$, hypertrophied hepatocytes obstruct the sinusoidal spaces in between $(\mathrm{H})$ (Hx \& E x 250).

3 - Photomicrograph of a section in liver of group II after $7^{\text {th }}$ day of treatment showing dilatation of portal vein $(\mathrm{PV})$, fatty degeneration $(\uparrow \uparrow)$ in presence of vacuolated cytoplasm $(\uparrow)(\mathrm{Hx} \& \mathrm{E} \times 250)$.

4- Photomicrograph of a section in liver of group II after $15^{\text {th }}$ days of treatment showing marked increase of kuffer cells (K) and vacuolated hepatocytic cytoplasm $(\uparrow)(\mathrm{Hx} \& \mathrm{E} \times 250)$. 


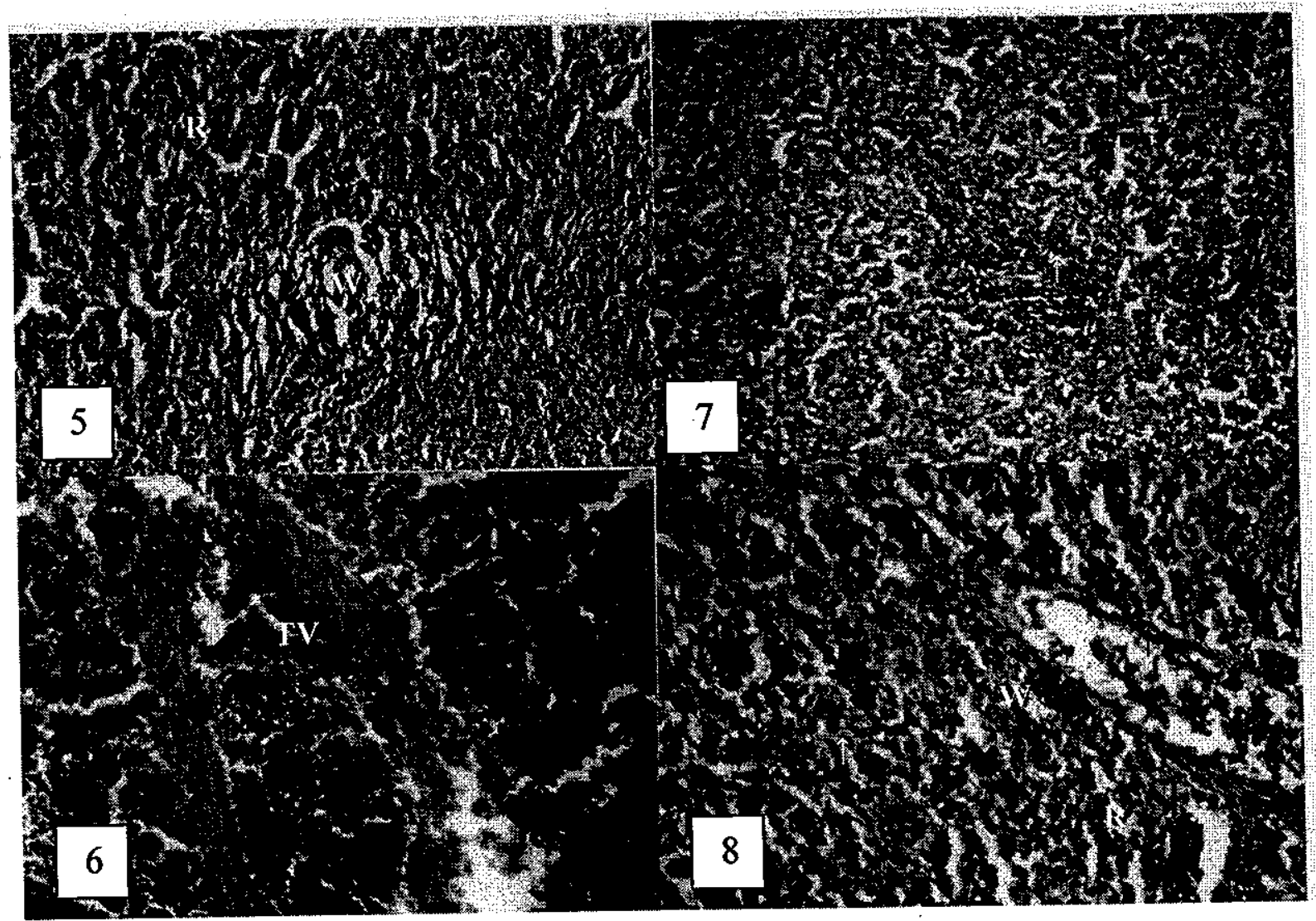

Fig. (2) Photomicrograph of a sections in spleen of control rat and experimental rat group (II).

5 - Photomicrograph of a section in spleen of control rat showing the normal histological structure of the white and red pulps (W \& R), central arteriole $(\uparrow)(H x \& E \times 250)$.

6- Photomicrograph of a section in the spleen of group II after $1^{\text {st }}$ day of partial hepatoectomy showing marked congestion of trabecular vessels (TV) with prominent internal hemorrhage ( $\uparrow$ ) (Hx \& E x 400).

7 - Photomicrograph of a section in the spleen after $7^{\text {th }}$ day of treatment, showing loss of its normal architecture and shrinkage white pulp $(\uparrow)(\mathrm{Hx} \& \mathrm{E} \times 250)$.

8 - Photomicrograph of a section in the spleen after $15^{\text {th }}$ day of treatment, showing pram put recovery both white and red pulps (W.R) in slight lymphocyte infiltration ( $\uparrow)(\mathrm{Hx} \& \mathrm{E} \times 400)$. 


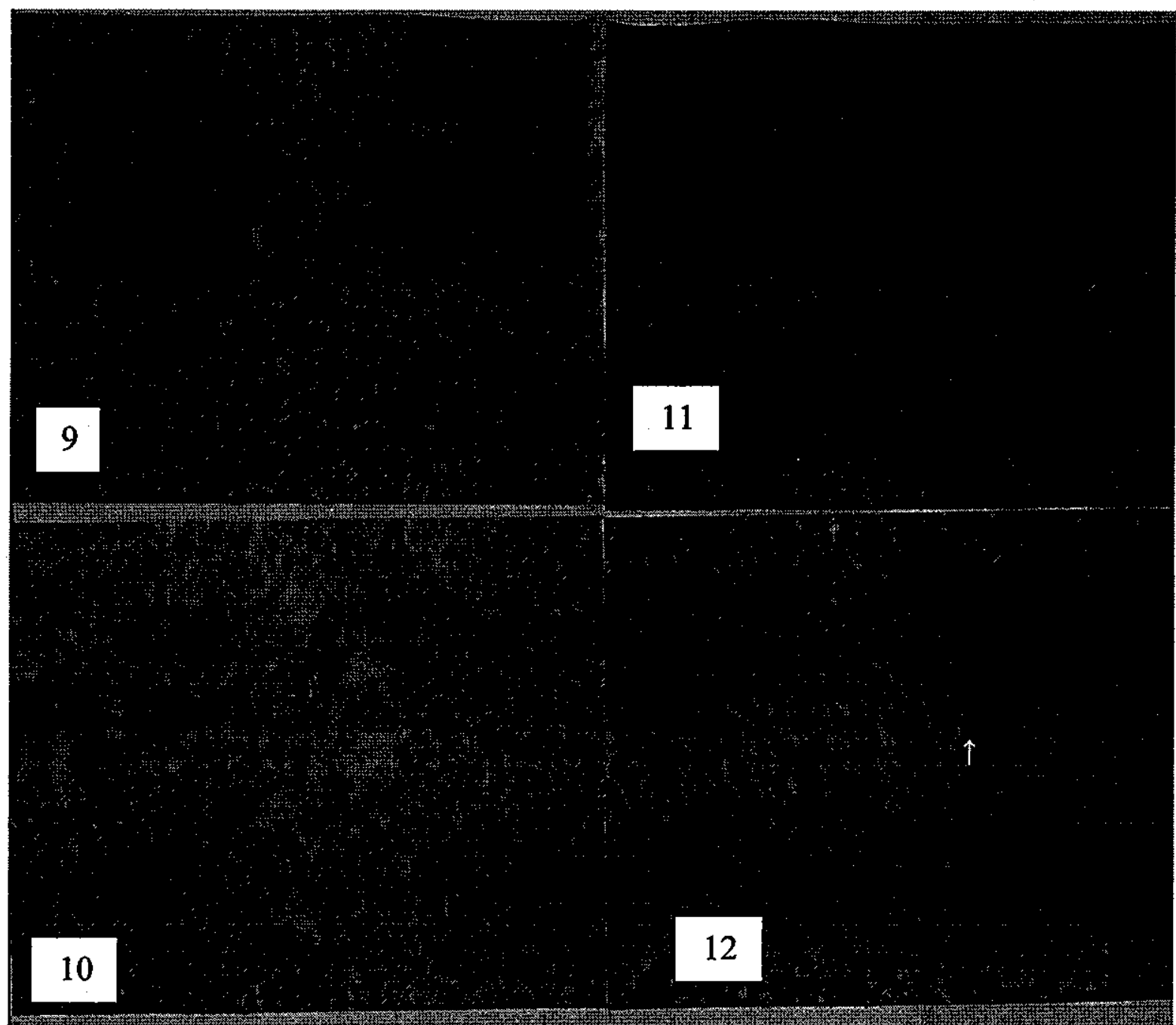

Fig. (3): Photomicrograph of a section in the rat liver and experimental rat group (II).

9- Photomicrograph of a section in liver of control rat showing moderate distribution of alkaline phosphatase activity as dark brown granules $(\uparrow)$ (Gomori's $\mathrm{x} 400)$.

10- Photomicrograph of a section in liver of group (II) after $1^{\text {st }}$ day of treatment showing decrease phosphatase activity in most of hepatocytes ( $\downarrow$ ) (Gomori's $x 250$ ).

11 - Photomicrograph of a section in liver of group (II) after $7^{\text {th }}$ days of treatment showing decrease alkaline phosphatase $(\downarrow)$ (Gomori's x250)

12 - Photomicrograph of a section in liver of group (II) after $15^{\text {th }}$ days of treatment showing moderate alkaline phosphatase activity $(\uparrow)$ (Gomori's $\mathrm{x} 250$ ). 
$\therefore$

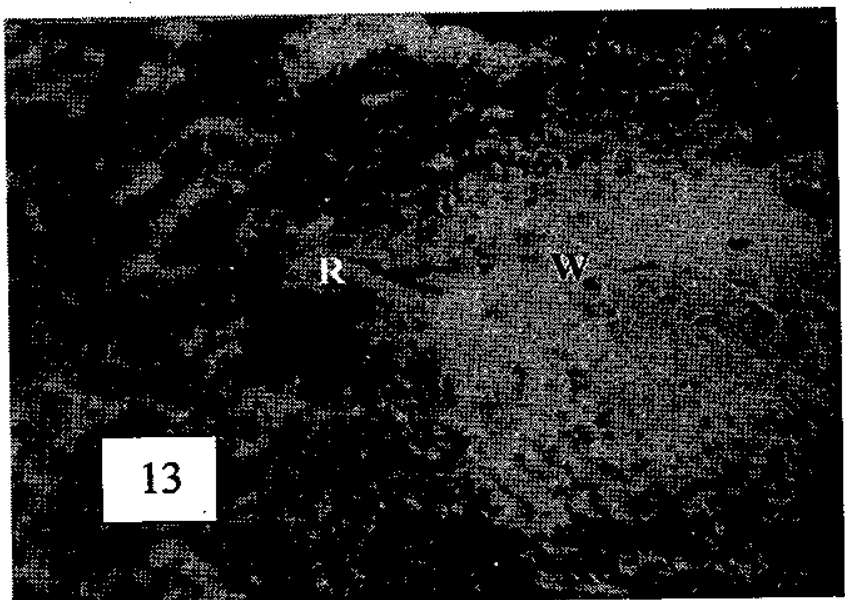

t.
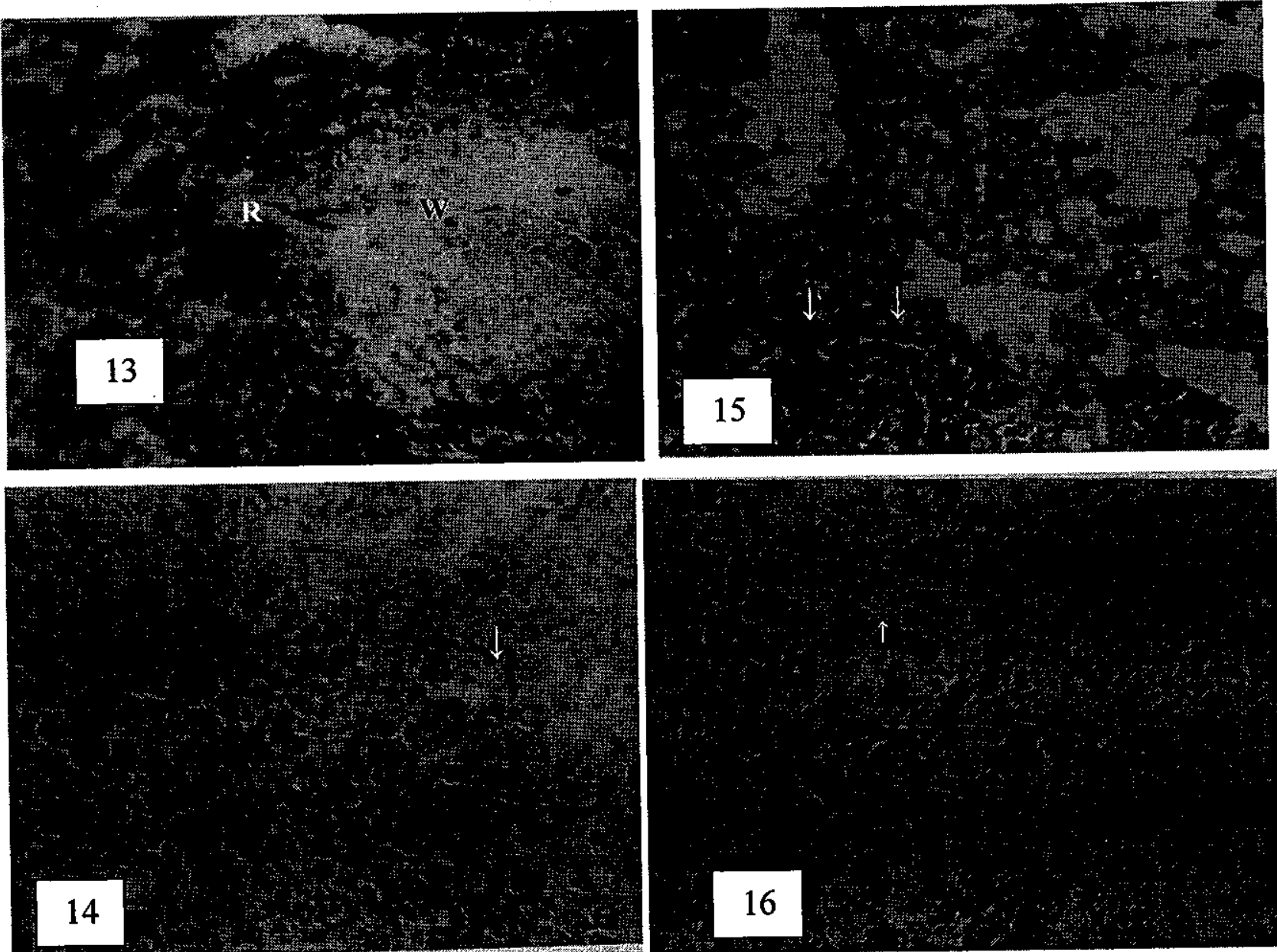

Fig (4): Photomicrograph of a section in the rat spleen and experimental rat group (II)

13 - Photomicrograph of a section in spleen of control rat showing negative white pulp (W) and positive red pulp phosphatase activity (R)(Gomori's $\mathrm{x} 400$ )

14 - Photomicrograph of a section in spleen of group (II) after $1^{\text {st }}$ day of treatment showing decrease alkaline phosphatase activity $(\downarrow)($ Gomori's $x 400)$

15 - Photomicrograph of a section in spleen of group (II) after $7^{\text {th }}$ days of treatment showing decrease in phosphatase activity $(\downarrow)$ (Gomori's $\times 400)$

16 - Photomicrograph of a section in spleen of group (II) after $15^{\text {th }}$ day of treatment showing moderate in phosphatase activity $(\uparrow)$ (Gomori's $\mathrm{x} 400$ ). 


\section{Discussion}

The problem of liver regeneration has come into focus during the past several decades. Many histological studies and recently a growing number of biochemical and histochemical investigations have been devoted to this important problem

In the present study, histological and histochemical parameters were applied in the liver and spleen of rats after $2 / 3$ partial hepatoectomy to detect its effects at varying intervals of time on $1^{\text {st }}, 7^{\text {th }}$ and $15^{\text {th }}$ days post-surgical operation.

These findings could be attributed to the regenerative process started on first post operation day by the compensation hypertrophy followed by increasing mitotic activity of hepatocytes with the maximum on the $\mathbf{3 0}$ hours after partial hepatoectomy.

Moreover, the histopathological data showed changes of spleen sections after $1^{\text {st }}$ and $7^{\text {th }}$ day of partial hepatoectomized rats including congestion of trabecular vessels, shrinkage of white pulp with loss of normal architecture, and widening of blood vessels with lymphocytic infiltration followed by marked recovery after $15^{\text {th }}$ day of treatment were detected. In fact, these results could explain an increase in the process of lipid peroxidation and a decrease in the activity of the antioxidant enzymes of the body with the consequent damage of cellular biomembranes El-Habit et al., (2000) and Saad et al (2001).

On the other hand, alkaline phosphatase enzyme is a membrane bound glycoprotein is used as a marker enzyme for the plasma membrane.

Among these,the data indicated a decrease of Alkaline phosphatase in the liver and spleen red pulp after $1^{\text {st }}$ and $7^{\text {th }}$ day post hepatectomy. The decrease in alkaline phosphatase activity is similar to different pathological conditions in response to various stimuli Knolwes et al, (1979), In starvation Moussa et al (1987), in case of mercury intoxification Sastry and Rao (1981), in insecticide treatment Mousa et al., (1987) and antibiotic treatment $\mathrm{El}$ Beih et al (1993), (1998) After radiation exposure Omaima et al, (2001). On the other hand, Melen et al., (1985) who studied the effect of lysosomal enzymes in plasma, Liver and spleen from rats with carbon tetrachloride induced liver cirrhosis and reported no consistent increase in plasma, spleen or liver lysosomal enzyme activates.It is concluded from the present data marked improvement of alkaline phosphatase in hepatectomized rats after $15^{\text {th }}$ days of treatment in both liver and spleen tissue section. These results could be beneficial when planning for radiotherapy programme in cancer patients,treatment of liver disease of different itiology including toxic hepatitis,antilipid peroxidative and liver degeneration.

\section{References}

1- El-Beih ZM, Amer MA and Elew FH (1993): Histoenzymology alterations in the succinic dehydrogenase activity in the cells of mice administered erylhromycin. Proc. Egypt. Acad., Sci., 43: 113-121.

2- El-Beih ZM, Amer MA and Atti, MA (1998): Effect of narcotics on the mitochandria and succinic dehydrogenase activity of the intestinal epithelial cells of mammals.Egypt. J. Histol., 2(2): 281-292.

3- El-Habit OM, Saada HN, Azb hSh, Abdel rhaman $M$ and El-Malah D.f (2000): J. Mutation. Res., 466-179.

4- Hakova $H$ and Misurova $E$.(1996): Therapeutical effect of silymarin on nucleic acids in the various organs of rats after radiation injury. Dep. Of cellular and molecular Biology. P.J. Safarik university, Kosice, slovakia 45(10). 910-912.

5- Higgins GM, Anderson QM (1931): Experimental pathology of the liver. 1Restoration of the liver white rat following partial surgical removal Arch path V.12 P. 187-202.

6- Knowles D, Hoffman H, Ferraini $M$ and Kunkel H (1979): Acid naphthyl acetate estrase activity in human neoplastic lymphoid cells. Americ. J. pathol 96: 257-278.

7- Kropacova $K$ Misurova $E$ and Hakova $H$ (1998): Protective and therapeutic effect of silymarin on the development of Latent liver damage. Radiats.Biol. Radiocol V38N 3 P4 11-5:

8- Maisin J K (1998): Int. J. Radiat, boil.72: 443-450.

9- Melen K, Hultberg B, Hager strand I, Is 
akssos A, Joelsson $B$ and Bengmark $S$ (1985): Lysosomal enzymes in plasma, Liver and spleen from rats with carbon tetra-chloride induced liver cirrhosis. Pub Med Identifier(PMID) 24 34453. Enzyme 33(2) : 84-8.

10- Moussa TA, El-Beih ZM and Amer MA (1987): Changes in the acid phosphatase and succinic dehydrogenase activities in mammalian gastric glandular cells induced by insecticide intoxication and starvation. Egypt. J. Histol .10(1): 129-138.

11- Nagino M, Nimura $Y$, Kamiya J, Kanai $M$ Uesaka $K$, Hayakawa $\mathbf{N}$ and Yamamoto H (1999): Serum alkaline phosphatase after extensive liver reaction: a study in patients with bilary tract carcinoma. Hepatogastroenterology PMID: 11180893.46(26): 766-70.

12- Omaima $S$ and Ashraf $M$ (2001). Histochemical studies on the role of Pantothnic acid on radiation damage of the kidney. The Egypt J. of Hospital Medicine. Vol 2:163-180.

13- Osada $S$ and Saji S (2004): The clinical significance of monitoring alkaline phosphatase level to estimate postoperative liver failure after hepatectomy PMID: 5532828 . Hepatogastroenterology 51(59): 1434-8.

14- Pearse AG (1975): Histochemistry theoretical and applied vol.3 Williams and Wilkins Co, Baltimave, London and New York.

15- Saada HN and Azab KS (2001): Role of lycopene in recovery of radiation induced injury to mammalian cellular organelles. $J$. Pharmazie. 56(3) : 239 .

16- Sastry KV and Rao DR (1981): Enzymological and biochemical changes produced by mercuric in a teleost fish, channa punctatus Toxicol. Letters. $9(4)$ : 421-326.

17- Ulieno O, Greksak M, Vancova $O$, Zlalos L, Galbavy B and Nakano $M$ (2003): Physio, Res. 52: 461-466. 


\section{دراسات هستولوجية وهستوكيمائية في كبد وطحال الجرذان بعد النزع الجزئي للكبد \\ د. نبيلة عبد الرحمن عبد المتعال \\ قسم بحوث بيولوجيا الأشعاع بالمركز القومي لبحوث وتكنولوجيا الأشعاع}

يهـدفُ هذا البحث إلى دراسة تأثير النزع الجزئي للكبد هستولوجيا وهستوكيمائيا على كبد وطحال الجوذان..

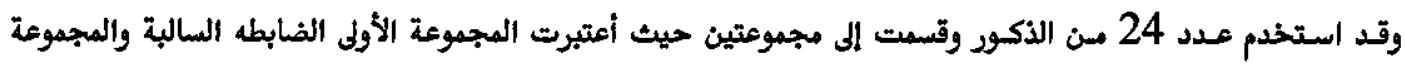

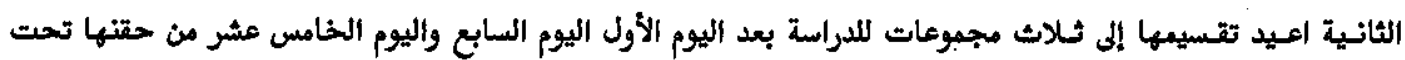

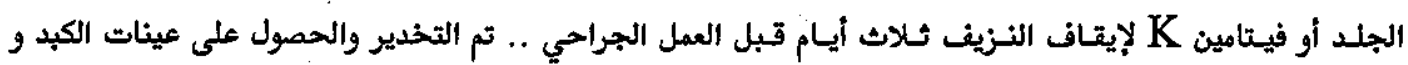

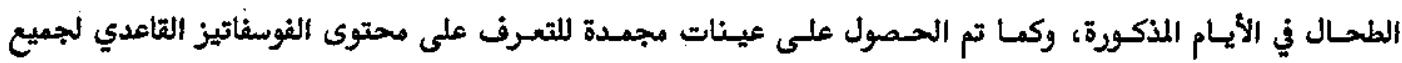
المجاميع ومقارنتها بالمجاميع الضابطه.

أوضحت نـتائج الفحس النسيجي للكبد والطحسال بعد العمل الجراحي حدوث تغنيرات واضحة من احتقان

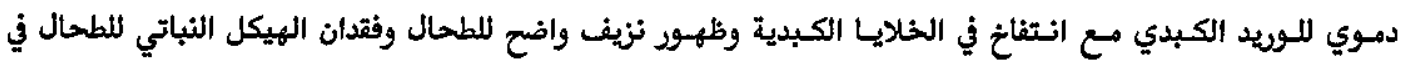
اليومين الأول والسابع من المعاملة ـ بينما اوضحت القطاعات النسيجية للكبد استعادة نشاط الخلايا الكبدية وكثرة خلايا

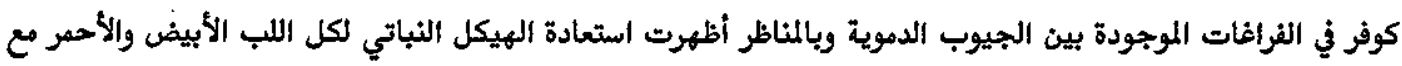
وجود الخلايا الالتهابية في الأوعيه الحوجزية لطحال الفئران المنزوعه الكبد. كما أظهرت النتائج نقص في نشاط الفوستاتيز القاعدي بعد اليوم الأول والسابع من العمل الجراحي في خلايا الكبد والطحـال وإحـداث تفاعل متوسط لمحتوى الفوستاتيز القاعدي في كل نسيجي الكبد والطحال بالمقارنه بالمجاميع 